Journal of Engineering and Applied Sciences 14 (1): 68-75, 2019

ISSN: 1816-949X

(C) Medwell Journals, 2019

\title{
Identifying the Factors Affecting Performance of Secondary and Higher Secondary Schools in India
}

\author{
Bishwarup Ghosh and Goutam Panigrahi \\ National Institute of Technology (NIT), Durgapur, India
}

\begin{abstract}
The importance of quality schooling is increasing day by day with country's progress. Schooling is the backbone of a country. Post liberalization private schools have mushroomed in the country questioning the quality of education imparted. This study focuses on the identification and assessment of factors affecting performance of secondary and higher secondary schools in India. The objective is also to calibrate the performance indicators and assess the inter-linkages among those factors. A survey using a questionnaire containing nineteen items is conducted with the help of 136 qualified and experienced secondary and higher secondary school teachers and the result shows that the factors can be grouped into five major dimensions. The impact of one dimension on the others are also tested through regression analysis.
\end{abstract}

Key words: Schooling, performance, factor analysis, regression, dimension, progress

\section{INTRODUCTION}

The importance of quality schooling is increasing day by day as the country progresses. Primary and secondary schooling is the backbone of a country. A place where students get their 1 st education, acts as the main foundation for their lives. Besides formal education, the students get to learn attitude, behavior, gesture and how to respect the others. Quality schooling impact career growth for individuals and thus, collectively plays a vital role in nation building (Betts, 1995). Before the era of privatization in India, schools were mainly governed by either the state or central government. But today lots of schools have emerged with a majority of them compromising with the quality. The stakeholders are confused in understanding how to evaluate the quality of education provided by those schools and thus, the assessment of a school often go wrong.

Education is a must for a promising and secure future and a stable life turns our dreams into reality. The success of the pupil in future is dependent on the quality of the school (Betts, 1995). It is therefore, extremely important for the parents to choose the best school considering their requirements. Since, there is no single criterion based on which one can decide the quality of a school, it becomes a daunting task for parents and guardians to understand the importance of multiple criteria and give importance to them in the evaluation. If a parent gives more emphasis on a comparatively less important factor, it may lead to wrong selection of a school for their child's education. This need led us select this topic as our research project. Our main objective is to find out key factors that determine the quality of school's performance and provide proper guideline to the stakeholders to select the best school for their child.

To understand the quality of a school one needs to evaluate it from multiple perspectives. This is a first step of applying Multiple Criteria Decision Making (MCDM) models where the schools are to be evaluated using multiple conflicting criteria. This study studies the existing literatures and identifies the factors affecting quality schooling. Further, the study tests the interrelations among those factors using regression analysis.

Literature review: To identify the factors evaluating the performance of the schools in India, the researchers have done a thorough review of the relevant literature. A number of researchers, including, Lezotte et al. (2002), have stated that good schools have unique characteristics and processes which help all children to learn at best way. Many studies have therefore been carried out to determine the factors for improving academic outcomes. In an study on school governance, teacher incentives and pupil-teacher ratios on Kenyan primary schools, Duflo et al. (2015) mentioned that education policymakers generally focus on bringing down pupil-teacher ratios. In their study they examined a program hiring an additional teacher on an annual contract renewable conditional on performance and identified large potential dynamic benefits from 
Table 1: Factors and Literature support

\begin{tabular}{|c|c|}
\hline Sub factor & Support in existing literature \\
\hline Student attendance & Mushtaq and Khan (2012) \\
\hline \multicolumn{2}{|l|}{ Family background of the student } \\
\hline Geographical location & Bertless (1996), Bulala et al. (2014) and Greenfiled et al. (2015) \\
\hline \multicolumn{2}{|l|}{ Transport facility } \\
\hline \multicolumn{2}{|l|}{ Physical resource } \\
\hline Teacher's qualification & Betts (1995), Lezotte et al. (2002), Njuguna et al. (2013), Bulala et al. (2014) and Hsu and Yuan-fang (2013) \\
\hline \multicolumn{2}{|r|}{ 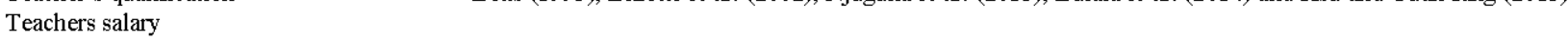 } \\
\hline \multicolumn{2}{|l|}{ Teachers motivation to teach } \\
\hline \multicolumn{2}{|l|}{ Teachers experience } \\
\hline \multicolumn{2}{|l|}{ Teacher student ratio } \\
\hline \multicolumn{2}{|l|}{ Behavior of the non-teaching staff } \\
\hline \multirow{2}{*}{\multicolumn{2}{|c|}{$\begin{array}{l}\text { Leadership } \\
\text { School governing body }\end{array}$}} \\
\hline & \\
\hline Learning material & Mushtaq and Khan (2012) \\
\hline \multicolumn{2}{|l|}{ Pedagogy } \\
\hline \multicolumn{2}{|l|}{ Curriculum } \\
\hline $\begin{array}{l}\text { Teaching learning environment } \\
\text { Safety }\end{array}$ & Betts (1995) and Douflo et al. (2015) \\
\hline Class size & \\
\hline
\end{tabular}

locally-hired contract teachers on a probationary basis. In his article on whether quality matters or not in schooling, Betts (1995) argued that the student outcomes are not independent of the quality of school they have undergone. There is a significant difference of the economic wellbeing of the students identified in the test. Makworo et al. (2014) in their article on factors affecting academic performance of the students in Kenyan context identified that there is a relationship between the teacher's attitude and student's learning in the schools of Kenya. This study captured the psychological factors affecting the girl student's attitude towards schooling.

In another study, Bulala et al. (2014) identified location is a factor to predict the performance in Botswana Junior School. The researchers have looked into the fact whether location of schools relates to the academic performance of students in Botswana. The results showed that there is heardly any difference between student's academic performance in rural, semi urban and urban secondary schools in examinations. The study has proven that school location has no bearing with performance of a student. However, the researchers never talked about the impact of location on the performance of the school as a whole.

In their study, Nyagosia (2011) determined the relationship between school effectiveness and academic performance of students. The study concludes that good leadership, focus on school mission, home-school relations, monitoring of student's progress, school safety and orderliness, expectations for success and opportunity to learn are the seven correlates good predictors of academic performance. In the assessment result of effective schools, stated that effective schools are correlated with student success. The seven common correlates identified are clear school mission, opportunity to learn and time on task, safe and orderly environment, high expectations for success, sound leadership positive home-school relations and frequent monitoring of student progress. In another study, Komba et al. (2013) examined factors affecting academic performance. They pointed out the following factors limited number of qualified teachers and number of students, lack of teaching and learning environment and shortage of teaching and learning materials, lack of reliable libraries and laboratories, weak communication and poor attendance by teachers, etc.

In the study on quality of service in schools, Wu at al. (2014) indicated that factors chiefly affecting quality of service was: government policy, school administration, teaching equipment and the ethos of the school, leadership, management, social change and globalization.

Based on the review of the existing literature, the identified factors influencing the performance of secondary and primary schools and are presented in Table 1. We found that there is a scarcity of research studies on secondary school performance in Indian context. The interrelations among those performance indicators are also not studied.

\section{MATERIALS AND METHODS}

Factor identification: A questionnaire was developed and mailed to 350 secondary and higher secondary teachers in West Bengal, India. These teachers are either working in a school or retired recently from school and with a minimum of 5 years to a maximum of 25 year's experience. A total of 136 responses were received resulting in a $39 \%$ response rate which is considered on the higher side for email surveys. The respondents were asked to mark the 
Table 2: Rotated component matrix

\begin{tabular}{|c|c|c|c|c|c|}
\hline \multirow[b]{2}{*}{ Rotated component matrix ${ }^{a}$} & \multicolumn{5}{|c|}{ Factors } \\
\hline & 1 & 2 & 3 & 4 & 5 \\
\hline Student attendance & & & & & 0.833 \\
\hline Geographical location & & 0.846 & & & \\
\hline Learning material & & & & 0.837 & \\
\hline Teaching learning environment & & & 0.786 & & \\
\hline Pedagogy & & & & 0.627 & \\
\hline School govemance & 0.608 & & & & \\
\hline Student family background & & & & & 0.870 \\
\hline Safety & & & 0.831 & & \\
\hline Teacher's qualification & 0.832 & & & & \\
\hline Teacher's salary & 0.720 & & & & \\
\hline School leadership & 0.605 & & & & \\
\hline Teacher's motivation & 0.733 & & & & \\
\hline Transport facility & & 0.712 & & & \\
\hline Teacher's experience & 0.654 & & & & \\
\hline Curriculum & & & & 0.865 & 0.064 \\
\hline Physical resource & & 0.808 & & & \\
\hline Class size & & & 0.654 & & \\
\hline Teacher student ratio & 0.598 & & & & \\
\hline Behavior of academic staff & 0.529 & & & & \\
\hline
\end{tabular}

importance of each factor on school's performance on a Likert-type scale ( 1 = "not important", $5=$ "very important") after providing his or her age and work experience. In this study, 19 sub factors (Table 2) were identified affecting performance of secondary or higher secondary schools in India.

Hypothesis development: We developed the following hypothesis from the existing literature and expert's opinion.

Teacher motivation: Naseer, Shereen, Nawaz, Shahbaz in Feb, 2012 has pointed out teacher motivation is the key to determine a school. Motivation directs behavior toward particular goals. Motivation conclude the specific objects toward which student strive. It is related the choices students make. Motivation increases effort and energy. Motivation determines enthusiasm or a lackluster attitude. Motivation increases the initiation and persistence of activities. So, motivated teacher is required to do so. Based on the review, hypothesis $\left(\mathrm{H}_{1}\right)$ was developed.

- $\mathrm{H}_{1}$ : teacher's motivation is positively correlated with student attendance

Teacher qualification: Chang and Yie (2006) indicated that teacher's qualification is important considerations when parents chose schools for their children. Teacher qualification is very much required to provide good education. But it is not always true that only good qualified teacher can create good ambiance for education. Based on the review, hypothesis $\left(\mathrm{H}_{2}\right)$ was developed.
- $\mathrm{H}_{2}$ : teacher's qualification is positively correlated with student attendance

Teacher student ratio: Duflo et al. (2015) indicated that how it is valuable entity for a school. It is the number of students who attend a school divided by the number of teachers in the institution. For the quality school the ratio should be less, so that, teacher can more focus on student. It is very important to understand a student attitude and behavior. Based on the review, hypothesis $\left(\mathrm{H}_{3}\right)$ was developed.

- $\mathrm{H}_{3}$ : Teacher student ratio is positively correlated with student attendance

Geographical location: Cowden and Funkhouser (2001) indicated that location is one of the key factor to choose the school. It is one of the crucial factor for gulf countries. The climate, language, religion and security is dependent on this factor. Based on the review, hypothesis $\left(\mathrm{H}_{4}\right)$ was developed.

- $\mathrm{H}_{4}$ : geographical location of the school is positively correlated with student attendance

Transport facilities: Oakey and Elliott (1982), Cowden and Funkhouser (2001) had proved that how it is important for the student. Most of the remote student prefers school transport facility to attend the school. The student sour rending the school prefers own transportation due to transportation time and cost. Based on the review, hypothesis $\left(\mathrm{H}_{5}\right)$ was developed.

- $\mathrm{H}_{5}$ : transport facilities is positively correlated with student attendance

Staff behavior: This was developed based on the feedback received from the senior teachers that everybody wants a good behavior and attitude of staff. Good behavior helps them to understand the progress of student and resolve any issue. Based on the review, hypothesis one $\left(\mathrm{H}_{6}\right)$ was developed.

- $\mathrm{H}_{6}$ : staff behavior is positively correlated with student attendance

Curriculum: Barneston pointed that as parents relied on word-of-mouth information when deciding where to send their children, schools should take advantage of advertising tools and adopt corresponding marketing strategies to impress potential students and their parents as well as other influencers. It means the medium of 
learning and board (CBSC/ICSC/STATE Gov.) school follows. Based on the review, hypothesis $\left(\mathrm{H}_{7}\right)$ was developed.

- $\mathrm{H}_{7}$ : curriculum is positively correlated with teacher's motivation (level of significance is more than 0.001 , so we accept dependent factors)

Pedagogy: Wu et al. (2014) stated that school quality directly related with pedagogy. It is a conscious activity by one person designed to adapt or inculcate the learning of another. So, it is always accepted by parents because one universal method may be not adopted by the all students. Based on the review, hypothesis $\left(\mathrm{H}_{8}\right)$ was developed.

- $\mathrm{H}_{8}$ : pedagogy is positively correlated with teacher's motivation

Learning material: Wu et al. (2014) indicates the equipment at the school has a direct influence on teaching. Excellent up to date equipment can facilitate multiple teaching methods and flexibility for students both in subjects and in methods of study (Cheng, 2005a, b; Gronroos, 1990) learning materials is directly proportional with the education learning system. Student always prefer the practical or lab oriented class rather than theoretical monotonous class. Based on the review, hypothesis $\left(\mathrm{H}_{9}\right)$ was developed.

- $\mathrm{H}_{9}$ : learning material is positively correlated with teacher's motivation

Teacher salary: Britton and Propper (2016) depicted the relationship between teacher salary and school quality. Teacher salary is related with the teacher motivation. As the teacher gets more salary he or she will be more dedicated to his reseasrch. Money is one always motivated factor. Based on the review, hypothesis $\left(\mathrm{H}_{10}\right)$ was developed.

- $\mathrm{H}_{10}$ : teacher salary is positively correlated with teacher's motivation

In the discussion with the experts, it is understood that better experienced teachers are motivated towards quality teaching. Based on this discussion hypothesis $\left(\mathrm{H}_{11}\right)$ was developed.

- $\mathrm{H}_{11}$ : teacher experience is positively correlated with teacher motivation

Class size: Akerhielm (1995) mentioned how class size is directly related with the school quality. If the class size is less, teacher can provide personalized attention to each students. Based on the review, hypothesis $\left(\mathrm{H}_{12}\right)$ was developed.

- $\mathrm{H}_{12}$ : class size is positively correlated with teacher's motivation

\section{RESULTS AND DISCUSSION}

In this study, the main focus was to identify and group the factors that affect the performance of secondary and higher secondary schools in India. The reliability analysis was conducted with the data and the result suggest a Cronbach's alpha value of 0.836 for the study. Usually the reliability coefficient, Cronbach's alpha value of above 0.7 is considered good in Indian context. In this study, the reliability analysis result showed a good amount of internal consistency.

A factor analysis was conducted to construct factors affecting school's performance based on the survey done with the teachers (Table 3 and 4).

Table 2 shows the rotated factor matrix for the survey. Because of cross loading the varimax rotation was performed and a loading more than 0.5 is considered in the study. Factor 1 (student) consists of 2 sub factors with a

\begin{tabular}{lccc}
\multicolumn{5}{l}{ Table 3: The total variance explained } \\
\hline \multicolumn{5}{c}{ Rotation sums of squared loadings } \\
\cline { 2 - 4 } Factors & Total & Variance $(\%)$ & Cumulative(\%) \\
\hline 1 & 3.219 & 16.940 & 16.940 \\
2 & 3.140 & 16.525 & 33.465 \\
3 & 3.048 & 16.041 & 49.506 \\
4 & 2.835 & 14.922 & 64.428 \\
5 & 2.268 & 11.936 & 76.364 \\
\hline
\end{tabular}

Table 4: Factors and sub-factors under each factors Factor/Items (Sub factor)

Student

Student attendance

Family background of the student

Infrastructure

Geographical location

Transp ort facility

Physical resource

Faculty and governance

Teacher's qualification

Teachers salary

Teachers motivation to teach

Teachers experience

Teacher student ratio

Behavior of the non-teaching staff

Leadership

School governing body

Teaching learning process

Learning material

Pedagogy

Curriculum

Academic ambience

Teaching learning environment

Safety

Class size

Overall reliability
0.773

0.791

\subsection{6}

0.718

0.818

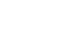


Table 5: Teacher's motivation, qualification and teacher students ratio on student attendance

\begin{tabular}{|c|c|c|c|c|c|}
\hline \multirow[b]{2}{*}{ Model\# } & \multicolumn{2}{|c|}{ Unstandardized coefficients } & \multirow{2}{*}{$\begin{array}{l}\text { Standardized coefficients } \\
- \text { Beta }\end{array}$} & \multirow[b]{2}{*}{$t$-values } & \multirow[b]{2}{*}{ Sig. } \\
\hline & $\mathrm{B}$ & SE & & & \\
\hline (Constant) & -0.754 & 1.242 & & -0.607 & 0.545 \\
\hline Teachers motivation to teach & 0.857 & 0.196 & 0.354 & 4.375 & 0 \\
\hline Teacher's qualification & -0.036 & 0.083 & -0.036 & -0.438 & 0.662 \\
\hline Teacher student ratio & 0.287 & 0.108 & 0.211 & 2.644 & 0.009 \\
\hline
\end{tabular}

\#Dependent variable: student attendance

Table 6: Geographical location, transport and behavior of non-teaching staff on student attendance

\begin{tabular}{|c|c|c|c|c|c|}
\hline \multirow[b]{2}{*}{ Model\# } & \multicolumn{2}{|c|}{ Unstandardized coefficients } & \multicolumn{3}{|c|}{ Standardized coefficients } \\
\hline & $\mathrm{B}$ & SE & Beta & $\mathrm{t}$-values & Sig. \\
\hline (Constant) & 5.57 & 0.789 & & 7.061 & 0.00 \\
\hline Geographical location & -0.468 & 0.189 & -0.231 & -2.48 & 0.014 \\
\hline Transp ort facility & 0.023 & 0.092 & 0.023 & 0.245 & 0.807 \\
\hline Behavior of the non-teaching staff & 0.308 & 0.053 & 0.438 & 5.764 & 0.00 \\
\hline
\end{tabular}

\#Dependent variable: student's attendance

Table 7: Curriculum, Pedagogy, Learning material on Teachers motivation to teach

\begin{tabular}{|c|c|c|c|c|c|}
\hline \multirow[b]{2}{*}{ Model\# } & \multicolumn{2}{|c|}{ Unstandardized coefficients } & \multicolumn{3}{|c|}{ Standardized coefficients } \\
\hline & B & SE & Beta & t-values & Sig. \\
\hline (Constant) & 2.322 & 0.427 & & 5.44 & 0.00 \\
\hline Curriculum & 0.373 & 0.076 & 0.423 & 4.913 & 0.00 \\
\hline Pedagogy & 0.78 & 0.112 & 0.625 & 6.985 & 0.00 \\
\hline Learning material & -0.675 & 0.131 & -0.522 & -5.173 & 0.00 \\
\hline
\end{tabular}

\#Dependent variable: teachers motivation to teach

Table 8: Curriculum, pedagogy, learning material on teachers motivation to teach

\begin{tabular}{|c|c|c|c|c|c|}
\hline \multirow[t]{2}{*}{ Model\# } & \multicolumn{2}{|c|}{ Unstandardized coefficients } & \multicolumn{3}{|c|}{ Standardized coefficients } \\
\hline & $\mathrm{B}$ & SE & Beta & $\mathrm{t}$-values & Sig. \\
\hline (Constant) & 1.244 & 0.347 & & 3.585 & 0.00 \\
\hline Teacher salary & 0.079 & 0.042 & 0.135 & 1.873 & 0.063 \\
\hline Teachers experience & 0.356 & 0.057 & 0.463 & 6.259 & 0.00 \\
\hline Class size & 0.375 & 0.08 & 0.308 & 4.678 & 0.00 \\
\hline
\end{tabular}

\#Dependent variable: teachers motivation to teach

loading of 0.833 and 0.87 . Factor 2 (Infrastructure) consists of $3 \mathrm{sub}$ factors with loading ranging between 0.71 and 0.846. Factor 3 (Faculty and governance) consists of 8 sub factors with factor loading ranging between 0.529 and 0.832 . Factor 4 (Teaching learning process) consists of 3 sub factors with loading ranging between 0.627 and 0.865 . Factor 5 consists of $3 \mathrm{sub}$ factors with factor loading ranging between 0.654 and 0.83 .

Table 3 displays the total variance explained at five stages for factors affecting performance of secondary and higher secondary schools in India. Five major factors were extracted as their eigenvalues were $>1$. These five factors cumulatively explain more than $76 \%$ of the variances.

The factor analysis resulted in five factors and are presented in Table 4. Bartlett's test of sphericity and the Kaiser-Meyer-Olkin measure of sampling adequacy are also conducted. The results show that Bartlett's test of sphericity is significant $(\mathrm{p}<0.001, \mathrm{p}=0.000)$ and the Kaiser-Meyer-Olkin measure is 0.684 which is $>0.6$.
Regression analysis was conducted to test the hypothesis $\mathrm{H}_{1}-\mathrm{H}_{12}$ and the results are presented in Table 5-8. Table 5 we can see that teacher's motivation to teach and teacher student ratio are significantly correlated with student attendance. Teacher qualification is not found to be non-significant.

Table 6 we can state that only behavior of the non-teaching staff is positively correlated with student attendance. Other factors like geographical location and transport facility are not found to be non-significant. Table 7 we can depict that all factors like curriculum, pedagogy, learning material are positively correlated with teachers motivation to teach.

Table 8 we can conclude that factors like class size, teachers experience are positively correlated with teachers motivation to teach whereas teacher salary is found to be partially-significant. Teacher qualification is very much required to provide good education. But it is not always true that qualified teacher can only create good ambiance for education. In Indian scenario, teacher's experience is 
Table 9: Hypothesis testing

\begin{tabular}{ll}
\hline Hypothesis & Results \\
\hline $\mathrm{H}_{1}$ & Sustained \\
$\mathrm{H}_{2}$ & Rejected \\
$\mathrm{H}_{3}$ & Rejected \\
$\mathrm{H}_{4}$ & Rejected \\
$\mathrm{H}_{5}$ & Rejected \\
$\mathrm{H}_{6}$ & Sustained \\
$\mathrm{H}_{7}$ & Sustained \\
$\mathrm{H}_{8}$ & Sustained \\
$\mathrm{H}_{9}$ & Sustained \\
$\mathrm{H}_{10}$ & Rejected \\
$\mathrm{H}_{11}$ & Sustained \\
$\mathrm{H}_{12}$ & Sustained \\
\hline &
\end{tabular}

found to be more important because of their adaptability to any situation. Our results also suggest the same. Teacher student ratio is found to be correlated insignificantly with student attendance which may be because of the size of student population vis-a-vis the number of teachers in the country. It is believed that less number of teachers can also perform the same job if they are highly motivated. In a country like India, self-conscientiousness and willingness plays a key role than the mare ratio. Geographical location is found to be non-significant. Generally, student from remote places prefer school transport facility to attend the school if they are not able to provide boarding facility. The results are found to be counter-intuitive in our study. Though employee salary is one of the most important motivating factors for performance in different sectors, it is not in the case of education in India. People consider this profession as a service to the nation rather than earning money and hence, may not be a huge influencing factor to determine the quality of schools in India (Table 9) (Appendix A).

\section{Appendix A; Measurement scales and items:}

- In measuring school's performance teacher's qualification is extremely unimportant, slightly unimportant, neither unimportant nor important, slightly important, extremely important

- In measuring school's performance school governance is

- In measuring school's performance teacher's salary is extremely unimportant, slightly unimportant, neither unimportant nor important, slightly important, extremely important

- In measuring school's performance school's leadership is extremely unimportant, slightly unimportant, neither unimportant nor important, slightly important, extremely important
- In measuring school's performance learning materials is extremely unimportant, slightly unimportant, neither unimportant nor important, slightly important, extremely important

- In measuring school's performance motivation and attitudes of teachers is extremely unimportant, slightly unimportant, neither unimportant nor important, slightly important, extremely important

- In measuring school's performance teaching pedagogy is extremely unimportant, slightly unimportant, neither unimportant nor important, slightly important, extremely important

- In measuring school's performance teachers' subject mastery and verbal skills is extremely unimportant, slightly unimportant, neither unimportant nor important, slightly important, extremely important

- In measuring school's performance teacher experience is extremely unimportant, slightly unimportant, neither unimportant nor important, slightly important, extremely important

- In measuring school's performance teaching and learning environment is extremely unimportant, slightly unimportant, neither unimportant nor important, slightly important, extremely important

- In measuring school's performance geographical location of the school is extremely unimportant, slightly unimportant, neither unimportant nor important, slightly important, extremely important

- In measuring school's performance safe and effective educational environment is extremely unimportant, slightly unimportant, neither unimportant nor important, slightly important, extremely important

- In measuring school's performance teacher to student ratio is extremely unimportant, slightly unimportant, neither unimportant nor important, slightly important, extremely important

- In measuring school's performance class size is extremely unimportant, slightly unimportant, neither unimportant nor important, slightly important, extremely important

- In measuring school's performance classroom condition is extremely unimportant, slightly unimportant, neither unimportant nor important, slightly important, extremely important

- In measuring school's performance age of the school is extremely unimportant, slightly unimportant, neither unimportant nor important, slightly important, extremely important

- In measuring school's performance transportation facility is extremely unimportant, slightly unimportant, neither unimportant nor important, slightly important, extremely important 
- In measuring school's performance culture of the staff is extremely unimportant, slightly unimportant, neither unimportant nor important, slightly important, extremely important

- In measuring school's performance student's attendance is extremely unimportant, slightly unimportant, neither unimportant nor important, slightly important, extremely important

- In measuring school's performance curriculum design is extremely unimportant, slightly unimportant, neither unimportant nor important, slightly important, extremely important

- In measuring school's performance parent's active participation is extremely unimportant, slightly unimportant, neither unimportant nor important, slightly important, extremely important

- In measuring school's performance medium of instruction is extremely unimportant, slightly unimportant, neither unimportant nor important, slightly important, extremely important

- In measuring school's performance physical resource other than class room is extremely unimportant, slightly unimportant, neither unimportant nor important, slightly important, extremely important

- In measuring school's performance student's family background is extremely unimportant, slightly unimportant, neither unimportant nor important, slightly important, extremely important

\section{CONCLUSION}

In the previous research studies researchers tried to identify different factors and their impact on the determination of quality of a school. Factors identified not only vary across countries but also the type of school within an area. However, the factors common across geographies can be grouped into quality of students, infrastructure, faculty and governance, teaching learning process and academic ambience. In this study we analyzed the existing literature and identified the sub factors therein and used the survey data to factor them into five major factors or groups. The developed scale proved to have good internal consistency. Result show that student attendance is significantly related to teacher's motivation to teach and behavior of the staff members. Teacher's motivation to teach is significantly related to curriculum, pedagogy, learning material, teacher's experience and class size.

\section{LIMITATIONS}

Like all other researches, this research also reports some limitations. First, we conducted this research based on respondents from in northern and eastern of part of India. One can question the generalizability of the results to other regions of India. Second, we considered 24 key factors in the study. However, more factors can be considered to get better insights.

\section{RECOMMENDATIONS}

In our future research one would calibrate the importance of those major factors and sub-factors using Fuzzy Analytical Hierarchy Process (FAHP) to determine a ranking of the secondary and higher secondary schools in India. Causality among these factors can also be studied in understanding the enablers of school performance in a dynamic environment.

\section{REFERENCES}

Akerhielm, K., 1995. Does class size matter?. Econ. Educ. Rev., 14: 229-241.

Bertless, G., 1996. The Link between Schools, Student Achievement and Adult Success. Brookings Institution, Washington, USA., Pages: 289.

Betts, J.R., 1995. Does school quality matter? Evidence from the national longitudinal survey of youth. Rev. Econ. Stat., 77: 231-250.

Britton, J. and C. Propper, 2016. Teacher pay and school productivity: Exploiting wage regulation. J. Publ. Econ., 133: 75-89.

Bulala, T., M. Ramatlala and H.J. Nenty, 2014. Location as a factor in the prediction of performance in Botswana junior school certificate agriculture examinations by continuous assessment scores. Creative Educ., 5: 1114.

Chang, D.F. and C.C. Yie, 2006b. Predicting change in the numbers of primary school students and the need for high quality teachers. Mon. J. Educ. Study, 151: 1531 .

Cheng, Y.S., 2005b. The study of the service quality. Mon. J. Qual., 41: 63-65.

Cheng, Y.T., 2005a. The effect of the low birth rate on the development of the primary school. Master Thesis, Taipei Educational University, Taipei, Taiwan.

Cowden, A.J. and E. Funkhouser, 2001. Adolescent pregnancy, infant mortality and source of payment for birth: Alabama residential live births, 1991-1994. J. Adolesc. Health, 29: 37-45.

Duflo, E., P. Dupas and M. Kremer, 2015. School governance, teacher incentives and pupil-teacher ratios: Experimental evidence from Kenyan primary schools. J. Publ. Econ., 123: 92-110.

Greenfield, J.R.F., M. Almond, G.P. Clarke and K.L. Edwards, 2015. Factors affecting school physical education provision in England: A cross-sectional analysis. J. Publ. Health, 38: 316-322. 
Gronroos, C., 1990. Service Management and Marketing Managing the Moments of Truth in Service Competition. Lexington Books, Lexington, MA., USA., ISBN: 9780669200355, Pages: 298.

Hsu, Y. and C. Yuan-Fang, 2013. An analysis of factors affecting parents choice of a junior high school. Intl. J. Bus. Hum. Technol., 3: 39-49.

Komba, C.K., E.L. Hizza and W.T. Jonathan, 2013. Factors influencing academic performance of ward secondary schools: A case of selected schools in Moshi municipality and Moshi District. Ph.D Thesis, MUCCoBS, Moshi, Tanzania.

Lezotte, L.W., R.D. Skaife and M.D. Holstead, 2002. Effective Schools-Only You can Make a Difference. All Star Publishing, Phoenix, Arizona,

Makworo, B.K., C.M. Wasanga and W. Olaly, 2014. Psychosocial factors that affect girls academic performance in secondary schools in Kenyenya, Kisii County, Kenya. Intl. J. Psychol. Counselling, 6: 119132 .
Mushtaq, I. and S.N. Khan, 2012. Factors affecting students' academic performance. Global J. Manage. Bus. Res., 12: 16-22.

Njuguna, F.W., S.N. Waweru and P.O. Nyagosia, 2013. Factors influencing academic achievement in public secondary schools in Central Kenya: An effective schools' perspective. Educ. Res. Intl., 2: 174-184.

Nyagosia, P., 2011. Determinants of differential Kenya certificate of secondary education performance and school effectiveness in Kiambu and Nyeri Counties. M.Ed Thesis, Kenyatta University, Nairobi, Kenya.

Oakey, N.S. and J.A. Elliott, 1982. Dissipation within the surface mixed layer. J. Phys. Oceanogr., 12: 171185.

Wu, S.W., C.Y. Lin, S.F. Wu, C.L. Chuang and H.Y. Kuan, 2014. Factors affecting quality of service in schools in Hualien, Taiwan. Procedia Soc. Behav. Sci., 116: 1160-1164. 